\title{
The effect of particular active substances of hallucinogenic mushrooms
}

\author{
MAREK WIECZOREK \\ Department of Neurobiology, Faculty of Biology and Environmental Protection, University of Lodz, \\ Lodz, Poland \\ E-mail: marek@biol.uni.lodz.pl
}

\begin{abstract}
Magic mushrooms have accompanied man for thousands of years. Formerly they were used for religious and culture purposes. Those fungi belong mainly to the genera Conocybe, Copelandia, Panaeolus, Psilocybe and Stropharia. A number of these fungal species produce substances, like psilocybin, psilocin, ibotenic acid or muscimol. Because of their chemical similarity to naturally occurring neurotransmitters like serotonin and GABA these substances, after ingestion, affect brain neurochemistry and by this induce hallucinations.

This mini review presents the influence of psilocybin, psilocin, ibotenic acid and muscimol on the nervous system. Also the effects of the above mentioned substances on emotion and mental health of people are discussed.
\end{abstract}

KEY WORDS: magic mushrooms, psilocin, psilocybin, ibotenic acid, muscimol

\section{Introduction}

Hallucinogenic mushrooms have accompanied man for thousands of years. Rock paintings, dated back to 3.500 years $\mathrm{BC}$, which were found in one of the caves in present Algeria, depict dancing figures, holding mushrooms in their hands. This thesis is also supported by similar findings from the region of Latin America. Numerous data suggest that hallucinogenic mushrooms were being used in Indian cultures of Mexico and Central America; the Aztecs' and the Maya's religious rituals were based on the consumption of mushrooms containing psilocybin. Although, the colonization, together with Christianization of those areas of America, led to the imposition of the official ban on their usage, the custom has survived in secret within the indigenous population, as it was proved later. Gordon Wasson in 1957 published in Life (Meyer \& Quenzer 2005) a description of the original Indian ritual, during which they used hallucinogenic mushrooms. That publication led to the popularization of those fungi within Western culture, especially among 
contemporary youth subcultures. Then hallucinogens, psilocin and psilocybin, produced by fungi were identified and the pharmaceutical company Sandoz has synthetized psilocybin. At the time, it was found that also in Europe hallucinogenic mushrooms can be commonly found (Meyer \& Quenzer 2005). In Poland, we meet that group of fungi, among which prevails Psilocybe semilanceata (Fr.) P. Kumm. (Sebelska 2013).

A number of fungal species produce alkaloids with hallucinogenic properties. Those fungi, which were often called magic mushrooms, belong mainly to the genera: Conocybe, Panaeolus (incl. = Copelandia), Psilocybe and Stropharia. Their effects, depending on the species of fungus, typically occur relatively fast after ingestion of a few grams of dry substance. Their influence appears about 30 minutes after ingestion and may maintain for several hours. Those fungi can be consumed in several forms: as dried material, fungus' brew or as a supplement to other food. In most fungi, hallucinogenic substance are psilocybin and its' active derivative, psilocin. After ingestion, psilocybin is enzymatically converted to psilocin, which in fact manifests psychoactive properties (Meyer \& Quenzer 2005).

Mushrooms containing psilocybin and psilocin are not the only that can affect the activity of the CNS. Other psychoactive compounds, which are present for instance in fly agaric (Amanita muscaria), should be mentioned. Psychoactive substances of that mushroom are muscimol, ibotenic acid and mukazon. Ingestion of fly agaric, in various forms, leads to a state resembling alcoholic intoxication (Meyer \& Quenzer 2005).

\section{The influence of psilocybin / psilocin on the nervous system}

Psilocybin, such as psilocin are metabolic products of a number fungi belonging mainly to the following genera: Conocybe, Inocybe or Psilocybe. The consumption even of a small amount of fungus, typically from 1 to 5 grams, leads to the appearance of a number somatic and psychological changes. Substances contained in them can cause heart disorders or neurodegenerative changes, especially if taken chronically. On the other hand, psilocybin, being a precursor of psilocin, in certain circumstances may cause mystical reactions. Altered states of consciousness, caused by religious beliefs are often being amplified by taking psychedelic substances. Intention behind that custom is to facilitate contact with ancestors or creation of prophecy. Those symptoms obviously are not free from side effects. In the state of impaired consciousness caused by the action of both psilocybin and psilocin, negative emotional experience, such as fear, undefined anxiety, shame and a feel of guilty may occur. Therefore, religious practices combined with the usage of psychedelic drugs, often lead to the disorder of psychosocial identification (Stebelska 2013). Such mental syndrome, caused by various reasons, is often dangerous and may be trigger the development of severe pathologies of mental nature, including states similar to some forms of schizophrenia (Hyde et al. 1978, McDonald 1980). Due to reasons mentioned above, psilocybin and psilocin are being currently used in animal models investigating substrates of schizophrenia (Stebelska 2013).

About $50 \%$ of psilocybin is absorbed after oral administration and, as shown by experimental data obtained with 
carbon $\mathrm{C}^{14}$, its' distribution in the body is rather uniform (Hopf \& Eckert 1974, Passie et al. 2002). In the body psilocybin under the influence of alkaline phosphatase, is the subject to dephosphorylation and is converted to psilocin, which is the main and perhaps the only substance showing psychopharmacological activity. About 8 hours after ingestion, the concentration of this substance in the tissues is very low, albeit in the liver and adrenal glands it remains even to about 48 hours (Hopf \& Eckert 1974, Passie et al. 2002, Stebelska 2013).

After oral administration of 3 to $5 \mathrm{mg}$ of psilocin, which depends on the individual characteristics of each organism, the first characteristic symptoms of excitation the sympathetic autonomic nervous system appear, while the hallucinogenic effects are not being observed, yet. All effects characteristic to psilocybin appears after about $70-90$ minutes after oral administration of 8 to $25 \mathrm{mg}$ of the substance. Research also indicates that about 30 minutes after taking psilocybin, psilocin appears in the plasma. Psilocin is a substance with lipophilic nature, and therefore may relatively easy pass blood - brain barrier (Passie et al. 2002).

Both psilocybin and psilocin possess the indole ring and belong to the same group of indolamines as serotonin, the endogenous CNS neurotransmitter. For this reason, similarly to the other hallucinogenic tryptamines, both; psilocybin and psilocin show resemblance to serotonergic system membrane receptors. The central effects of psilocybin and psilocin run mainly with the participation of $5-\mathrm{HT}_{2 \mathrm{~A}}$ receptor. That was confirmed by using an antagonist of these receptors, ketanserin, which prevented the development of the most psychotic symptoms caused by psilocybin or psilocin administration. However, as Stebelska (2013) reported in her review article, some of the effects of these tryptamines shall not be removed, and would even undergo intensification. This is particularly the weakening of cognitive response, expressed as difficulty in maintaining attention and reduced vigilance (Carter et al. 2005, Delgado \& Moreno 1998, Stebelska 2013). The same author, summarizing the cited results, states that the serotonergic system is responsible for the psychotic effects of these substances, by the excitation of $5-\mathrm{HT}_{2 \mathrm{~A}}$ receptors within areas of the cerebral cortex, but also by the combination with the presynaptic 5HT1A receptors, which are found in serotonergic cells within the dorsal raphe nucleus (DRN). Psilocin leads to deactivation of nerve cells within the DRN, which resembles that observed during REM sleep. Consequently, it leads to a reduction in serotonin release from terminals of ascending serotonergic projections to the cortex (Stebelska 2013, Carter et al. 2005). This type of reduction in the concentration of serotonin in serotonergic projection target area, beginning in the DRN, may lead to the occurrence of hallucinations similar to those that occur among people suffering from schizophrenia (Aghajanian \& Marek 1999, Gonzalez-Maeso \& Sealfon 2009).

Because psilocin is a derivative of tryptamine, therefore its inactivation in the body takes place with the participation of the same enzymatic processes as serotonin. This mainly concerns the action of monoamine oxidase, an enzyme naturally occurring within the synapses in the central nervous system and involved in the deactivation of monoaminergic neurotransmitters, which are released into the synaptic cleft. Therefore, the usage of monoamine 
oxidase inhibitors can intensify the psilocin activity; its hallucinogenic effects may be stronger and last longer (Halpern 2004).

Psychotic states and hallucinations that occur after the ingestion of psilocin can often return, what is known as the effect of "flashback". This phenomenon occurs especially when psilocin is combined with other substances, such as alcohol or marijuana (Ikeda et al. 2005, Stebelska 2013). Although psilocybin and psilocin are not strongly addictive substances, in some cases can become extremely dangerous for people who are taking them. This applies especially to young people, often emotionally instable due to their individual development. There have been noted some fatal cases, in which, after taking magic mushrooms, the person receiving them jumped out of the window. This may indicate a strong emotional destabilization or, what is characteristic to hallucinations caused by these substances, the phenomenon of waking dream, often accompanied by a feeling of floating or even possessing the ability to fly (Muller et al. 2013, Stebelska 2013).

\section{The influence of ibotenic acid and muscimol on the nervous system}

Ibotenic acid and muscimol, are substances produced by fungi of the genus Amanita, in case of which, they repel insects and larvae feeding on their fruit bodies (Halpern 2004, Tsujikawa et al. 2006). These fungi are widely present throughout the world, they are also common in Poland.

Due to the chemical structure of its' molecule, ibotenic acid shows resemblance to receptors of naturally occurring excitatory amino acid in the nervous system, the glutamic acid. While, muscimol is a $\mathrm{GABA}_{\mathrm{A}}$ receptor agonist, whose natural ligand in the nervous system is $\gamma$-aminobutyric acid. Unlike muscimol, ibotenic acid, due to its cytotoxic property is much more dangerous. It is being used in animal test models, in order to damage specific brain regions, which are characteristic, inter alia, for the changes seen in Alzheimer's disease (Halpern 2004, Stebelska 2013, Tsujikawa et al. 2006).

In the body, ibotenic acid is metabolized to muscimol, which has the ability to pass across the blood-brain barrier. This compound connects to mentioned $\mathrm{GABA}_{\mathrm{A}}$ receptors mainly in the areas of the forebrain, including the caudate nucleus and putamen, the thalamus and the hippocampal formation. This leads to opening of the receptor associated with the chloride ion channel, which in turn leads to inhibition of neuronal activity, where these receptors are located (Stebelska 2013).

According to Stebelska (2013), psychedelic effects occur after taking approximately $6 \mathrm{mg}$ of muscimol. However, in case of ibotenic acid that dose varies from 30 to $60 \mathrm{mg}$, which fulfils intake of one fly agaric fruit body with the mass of about 70 grams (Satora et al. 2005, Stebelska 2013). The first symptoms of ingestion of fungus occur relatively quickly, just after 15 to 30 minutes. They are usually nausea, vomiting, diarrhea, vasodilatation, sweating and salivation. Interesting effect of hallucinogenic that occurs after eating of fly agaric is the phenomenon called macroscopia. It consists of a vision of surrounding objects as much bigger than they are in reality. In case of humans, ingestion of relatively large dose of muscimol leads to hyperthermia, mydriasis, mood improval, concentration difficulties, anorexia, ataxia, catalepsy and hallucination. A number of these 
changes, resembling drunkenness, is also characteristic to the effects caused by the classical hallucinogen such as LSD (Meyer \& Quenzer 2005). Fly agaric

\section{Conclusions}

Hallucinogenic mushrooms have being eaten for thousands of years for ritual and religious purposes. Active substances, like psilocybin, psilocin and muscimol characterizes with relatively low toxicity and usually do not cause addiction typical to cocaine or opiates. However, due to the nature of the induced hallucinations and individual organism features such as age or emotional state, they may become dangerous to health. In turn, their resemblance to the serotoninergic system, and consequent ability to interact with other neurotransmitter systems of the brain are danger, because can lead to

\section{References}

Aghajanian, G.K. \& Marek, G.J. 1999. Serotonin and hallucinogens. Neuropsychopharmacology, 21: $16 \mathrm{~S}-23 \mathrm{~S}$.

Carter, O.L., Pettigrew, J.D., Hasler, F., Wallis, G.M., Liu, G.B., Hell, D. \& Vollenweider, F.X. 2005. Modulating the rate and rhythmicity of perceptual rivalry alternations with the mixed 5-HT2A and 5-HT1A agonist psilocybin. Neuropsychopharmacology, 30: 1154-1162.

Delgado, P.L. \& Moreno, F.A. 1998. Hallucinogens, serotonin and obsessivecompulsive disorder. J Psychoactive Drugs, 30: 359-66.

Gonzalez-Maeso, J. \& Sealfon, S.C. 2009. Psychedelics and schizophrenia. Trends Neurosci, 32: 225-232.

Halpern, J.H. 2004. Hallucinogens and dissociative agents naturally growing in the United States. Pharmacol Ther, 102: 131-138.

Hopf, A. \& Eckert, H. 1974. Distribution patterns of 14-C-psilocin in the brains of various animals. Act Nerv Super (Praha), 16: 64-66.

Hyde, C., Glancy, G., Omerod, P., Hall, D. \& Taylor, G.S. 1978. Abuse of indigenous psilocybin mushrooms: a new fashion and some psychiatric complications. $\mathrm{Br} \mathrm{J}$ Psychiatry, 132: 602-604.

Ikeda, A., Sekiguchi, K., Fujita, K., Yamadera, H. \& Koga, Y. 2005. 5-methoxy-N,N- poisoning symptoms persist relatively long and disappear after about 8 hours of ingestion of mushrooms (Satora et al. 2005).

psychosis, often specific to those occurring among patients suffering from schizophrenia. Regardless to the dangers associated with the consumption of hallucinogenic mushrooms, as well as active substances produced by them, it should be noted that the latterly mentioned are being commonly used in clinical neurophysiology. Being agonists or antagonists of membrane receptors for certain neurotransmitters, they help in understanding their physiological functions and point out possible pathologies caused by abnormalities within the particular neurotransmitter systems.

diisopropyltryptamine-induced flashbacks. Am J Psychiatry, 162: 815.

McDonald, A. 1980. Mushrooms and madness. Hallucinogenic mushrooms and some psychopharmacological implications. Can J Psychiatry. 25: 586-594.

Meyer, J.S. \& Quenzer, L.F. 2005. Psychopharmacology. Drugs, the Brain, and Behavior. Sinauer Associates, Inc. Sunderland, Massachusetts, USA.

Muller, K., Puschel, K. \& Iwersen-Bergmann, S. 2013. Suicide under the influence of "magic mushrooms". Arch Kriminol, 231: 193-198.

Passie, T., Seifert, J., Schneider, U. \& Emrich, H.M., 2002. The pharmacology of psilocybin. Addict Biol, 7, 357-364.

Satora, L., Goszcz, H. \& Ciszowski, K. 2005. Poisonings resulting from the ingestion of magic mushrooms in Krakow. Przegl Lek, 62, 394-396.

Stebelska, K. 2013. Fungal hallucinogens psilocin, ibotenic acid, and muscimol: analytical methods and biologic activities. Ther Drug Monit, 35: 420-442.

Tsujikawa, K., Mohri, H., Kuwayama, K., Miyaguchi, H., Iwata, Y., Gohda, A., Fukushima, S., Inoue, H. \& Kishi, T. 2006. Analysis of hallucinogenic constituents in Amanita mushrooms circulated in Japan. Forensic Sci Int. 164: 172-8. 


\section{Streszczenie \\ Działanie niektórych substancji aktywnych grzybów halucynogennych}

Grzyby halucynogenne towarzyszą człowiekowi od tysięcy lat. Malowidła naskalne datowane na 3500 lat przed naszą erą, które odnaleziono $\mathrm{w}$ jednej z jaskiń na terenie dzisiejszej Algerii, przedstawiają tańczące postacie, trzymające w rękach grzyby. Potwierdzają to również znaleziska archeologiczne z rejonów Ameryki Łacińskiej. Liczne dane wskazują, że grzyby halucynogenne stosowano w kulturach Indian Meksyku i Centralnej Ameryki, Azteków i Majów w rytuałach religijnych, związanych z ich życiem, a opartych na spożywaniu grzybów zawierających psylocybinę. Co prawda, kolonizacja i chrystianizacja tych rejonów Ameryki doprowadziła do wprowadzenia oficjalnego zakazu ich stosowania jednak, jak później dowiedziono, zwyczaj przetrwał w tajemnicy wśród rdzennej ludności. Gordon Wasson w 1957 roku opublikował w Life opis oryginalnego indiańskiego rytuału, podczas którego wykorzystano grzyby halucynogenne (Meyer \& Quenzer 2005). Wspomniana publikacja doprowadziła do spopularyzowania tych grzybów w kulturze Zachodu, szczególnie w ówczesnych subkulturach młodzieżowych. Następnie zidentyfikowano związki halucynogenne, psylocynę i psylocybinę, produkowane przez grzyby, a firma farmaceutyczna Sandoz wprowadziła na rynek psylocybinę (Meyer \& Quenzer 2005). W tym samym czasie stwierdzono, że także w Europie powszechnie występują grzyby o działaniu halucynogennym. W Polsce spotykamy tę grupę grzybów, wśród których zdecydowanie dominuje łysiczka lancetowata (Psilocybe semilanceata) (Stebelska 2013).

Szereg gatunków grzybów wytwarza alkaloidy o właściwościach halucynogennych. Grzyby te, często określane jako grzyby magiczne, należą głównie do rodzajów Conocybe, Copelandia, Panaeolus, Psilocybe oraz Stropharia. Efekty ich działania, zależnie od gatunku grzyba, pojawiają się zwykle po zażyciu już kilku gramów suchej substancji stosunkowo szybko, po upływie około 30 minut po spożyciu i utrzymują do kilku godzin. Zróżnicowana może być także postać, w jakiej grzyb jest spożywany; może to być materiał wysuszony, przygotowany napar lub grzyb przygotowany jako dodatek do innego pokarmu. W przypadku większości grzybów halucynogennych substancją aktywną jest psylocybina oraz jej pochodna, psylocyna. Po spożyciu, psylocybina podlega enzymatycznemu przekształceniu do psylocyny, która to $\mathrm{w}$ rzeczywistości przejawia własności psychoaktywne (Meyer \& Quenzer 2005).

Grzyby zawierające psylocynę i psylocybinę nie są jedynymi, które mogą wpływać na aktywność OUN. Należy zwrócić uwagę także na inne związki psychoaktywne, które występują choćby w muchomorze czerwonym (Amanita muscaria). Substancje psychoaktywne tego grzyba to muscimol, kwas ibotenowy i mukazon. Spożycie muchomora czerwonego, w różnej postaci, prowadzi do stanu przypominającego upojenie alkoholowe (Meyer \& Quenzer 2005).

\section{Wpływ psylocybiny/psylocyny na uklad nerwowy}

Zarówno psylocybina, jak też psylocyny są produktami metabolizmu szeregu grzybów należących między innymi do rodzajów Conocybe, Inocybe lub Psilocybe. Spożycie niewielkiej ilości grzybów, zwykle od 1 do 5 gramów, prowadzi do pojawienia się szeregu zmian, tak somatycznych jak i psychicznych. Substancje w nich zawarte, mogą wywoływać zaburzenia pracy serca czy zmiany neurodegeneracyjne 
szczególnie, jeśli są przyjmowane chronicznie. Z drugiej strony psylocybina, będąca prekursorem psylocyny, w określonych warunkach może wywoływać reakcje mistyczne. Stany zmienionej/odmiennej świadomości, powodowane wierzeniami religijnymi, często są „wzmacniane” przyjmowaniem substancji psychodelicznych, co w zamierzeniach ma powodować ułatwienie kontaktu ze światem przodków lub kreowaniu przepowiedni. Tego rodzaju symptomy nie są jednak wolne od efektów ubocznych stosowania wspomnianych substancji. W stanie zaburzeń świadomości powodowanej działaniem psylocybiny/psylocyny, mogą pojawiać się negatywne doznania emocyjne, jak choćby strach, nieokreślony lęk, wstyd oraz poczucie winy. Tym samym, wszelkie praktyki o charakterze kultu religijnego, w połączeniu $\mathrm{z}$ zastosowaniem środków psychodelicznych, prowadzą często do zaburzeń identyfikacji psychosocjalnych (Stebelska 2013). Tego rodzaju syndrom psychiczny, wywoływany z różnych powodów, często jest niebezpieczny i może stanowić początek rozwoju poważnych patologii o charakterze psychicznym, w tym podobnych w przebiegu do niektórych postaci schizofrenii (Hyde et al. 1978, McDonald 1980). Z tego powodu psylocybina lub psylocyna są obecnie stosowane w modelach zwierzęcych badających podłoże schizofrenii (Stebelska 2013).

Około $50 \%$ psylocybiny podlega absorpcji po podaniu doustnym, a jak wskazują dane doświadczalne uzyskane z zastosowaniem związku znakowanego izotopem węgla $\mathrm{C}^{14}$, jej dystrybucja w organizmie jest mniej więcej równomierna (Hopf \& Eckert 1974, Passie et al. 2002). W organizmie, psylocybina, pod wpływem zasadowej fosfatazy, podlega procesowi defosforylacji i przekształcana jest do psylocyny, która jest główną, prawdopodobnie jedyną, substancją aktywną psychofarmakologicznie. Po upływie około 8 godzin od zażycia, stężenie substancji w tkankach jest bardzo niskie, jednak w wątrobie i nadnerczach utrzymuje się do około 48 godzin (Hopf \& Eckert 1974, Passie et al. 2002, Stebelska 2013).

Po doustnym przyjęciu od 3 do $5 \mathrm{mg}$ psylocyny, co uzależnione jest od indywidualnych cech każdego organizmu, pojawiają się pierwsze objawy charakterystyczne dla wzbudzenia części współczulnej autonomicznego układu nerwowego, natomiast brak jeszcze efektów halucynogennych. Wszystkie efekty, charakterystyczne dla psylocybiny, zaznaczają się po upływie około 70-90 minut po doustnym przyjęciu od 8 do $25 \mathrm{mg}$ tej substancji. Badania wskazują również, że około 30 minut po przyjęciu psylocybiny, w osoczu krwi pojawia się psylocyna. Psylocyna jest substancją o charakterze lipofilnym, dlatego stosunkowo łatwo przechodzi barierę krew - mózg (Passie et al. 2002).

Zarówno psylocybina, jak i psylocyna posiadają pierścień indolowy i należą do tej samej grupy indoloamin, w której znajduje się serotonina, endogenny neurotransmiter ośrodkowego układu nerwowego. $Z$ tego powodu, podobnie do innych tryptamin o charakterze halucynogennym, wykazują powinowactwo do receptorów błonowych układu serotoninergicznego. Ośrodkowe efekty działania psylocybiny i psylocyny przebiegają głównie przy udziale receptora 5-HT $2 \mathrm{~A}$. Potwierdzono to stosując antagonistę wspomnianych receptorów, ketanserynę, która zapobiegała rozwojowi większości objawów psychotycznych powodowanych podaniem psylocybiny lub psylocyny. Jednakże, jak podaje w swojej pracy przeglądowej Stebelska (2013), niektóre efekty działania tych tryptamin nie zostają zniesione, a nawet ulegają nasileniu. Dotyczy to szczególnie osłabienia reakcji kognitywnych, wyrażanych trudnością w utrzymaniu uwagi oraz obniżeniem czujności (Carter et al. 2005, Delgado 
\& Moreno 1998, Stebelska 2013). Ta sama Autorka, podsumowując cytowane wyniki badań stwierdza, że system serotoninergiczny odpowiada za psychotyczne efekty działania tych substancji, zarówno przez wzbudzenie receptorów 5- $\mathrm{HT}_{2 \mathrm{~A}} \mathrm{w}$ obrębie obszarów kory mózgowej, ale także przez połączenie się z presynaptycznymi receptorami 5-HT $1 \mathrm{~A}$, które znajdują się $\mathrm{w}$ obrębie komórek serotoninergicznych grzbietowego jądra szwu. Psylocyna prowadzi do wyłączenia aktywności komórek nerwowych w obrębie grzbietowego jądra szwu (DRN), które przypomina to, obserwowane podczas snu REM. W konsekwencji doprowadza to do obniżenia uwalniania serotoniny $\mathrm{z}$ zakończeń wstępującej, dokorowej projekcji serotoninergicznej (Stebelska 2013, Carter et al. 2005). Tego typu obniżenie stężenia serotoniny $\mathrm{w}$ docelowych obszarach projekcji serotoninergicznej, rozpoczynającej się w obrębie grzbietowego jądra szwu, może doprowadzić do występowania halucynacji podobnych do tych, które występują u osób cierpiących na schizofrenię (Aghajanian \& Marek 1999, Gonzalez-Maeso \& Sealfon 2009).

Ponieważ psylocyna jest pochodną tryptamin, dlatego jej dezaktywacja w organizmie przebiega przy udziale tych samych procesów enzymatycznych, którym podlega serotonina. Dotyczy to przede wszystkim działania monoaminooksydazy, enzymu naturalnie występującego w obrębie synaps w ośrodkowym układzie nerwowym i uczestniczącego w dezaktywacji neurotransmiterów monoaminergicznych, uwalnianych do przestrzeni synaptycznej. Dlatego zastosowanie inhibitorów monoaminooksydazy nasila działanie psylocyny, efekty halucynogenne mogą być silniejsze i utrzymują się dłużej (Halpern 2004).

Stany psychotyczne i halucynacje, które występują po przyjęciu psylocyny mogą często nawracać, co znane jest jako efekt ,flashback”. Zjawisko to pojawia się szczególnie wtedy, gdy psylocyna łączona jest z innymi substancjami, jak choćby alkohol lub marihuana (Ikeda et al. 2005, Stebelska 2013). Mimo, że psylocybina i psylocyna nie są substancjami silnie uzależniającymi, to jednak w niektórych przypadkach mogą być wyjątkowo niebezpieczne dla osób, które je zażywają. Dotyczy to szczególnie ludzi młodych, często niezrównoważonych emocjonalnie w związku z rozwojem osobniczym. Zanotowano kilka przypadków śmiertelnych, w których po zażyciu magicznych grzybów, osoby je przyjmujące wyskakiwały przez okno. Może to wskazywać na silną destabilizację emocjonalną albo, co jest charakterystyczne dla halucynacji wywoływanych prze te substancje, zjawiska snu na jawie, któremu często towarzyszy uczucie unoszenia się lub nawet umiejętności fruwania (Muller et al. 2013, Stebelska 2013).

\section{Działanie kwasu ibotenowego i muscimolu w układzie nerwowym}

Kwas ibotenowy oraz muscimol, to substancje, które są wytwarzane przez grzyby z rodzaju Amanita, w przypadku których odstraszają owady oraz larwy, żerujące na ich owocnikach (Halpern 2004, Tsujikawa et al. 2006). Grzyby te są szeroko rozpowszechnione w całym świecie, występują również często w Polsce.

Ze względu na chemiczną budowę cząsteczki, kwas ibotenowy wykazuje powinowactwo do receptorów naturalnie występującego w układzie nerwowym aminokwasu pobudzającego, kwasu glutaminowego. Z kolei muscimol jest agonistą receptora $\mathrm{GABA}_{\mathrm{A}}$, którego naturalnym ligandem w układzie nerwowym jest kwas $\gamma$ aminomasłowy. W odróżnieniu od muscimolu, kwas ibotenowy, ze względu na swoje własności cytotoksyczne jest znacznie bardziej niebezpieczny. Jest on stosowany w 
modelach badań na zwierzętach, w celu uszkodzeń wybranych obszarów mózgu, które są charakterystyczne między innymi dla zmian obserwowanych w chorobie Alzheimera (Halpern 2004, Stebelska 2013, Tsujikawa et al. 2006).

W organizmie, kwas ibotenowy jest metabolizowany do muscimolu, który ma zdolność do przechodzenia przez barierę krew-mózg. Związek ten łączy się ze wspomnianymi receptorami $\mathrm{GABA}_{\mathrm{A}}$, głównie w obszarach przodomózgowia, między innymi w obrębie jądra ogoniastego i przegrody, wzgórza oraz formacji hipokampa. Powoduje to otwarcie związanego z tym receptorem kanału dla jonu chlorkowego, co w efekcie prowadzi do zahamowania aktywności neuronów, na których znajdują się wspomniane receptory (Stebelska 2013).

Jak podaje Stebelska (2013), efekty psychodeliczne pojawiają się po zażyciu około $6 \mathrm{mg}$ muscimolu. Natomiast w odniesieniu do kwasu ibotenowego dawka ta mieści się w przedziale 30 do $60 \mathrm{mg}$, co odpowiada mniej więcej spożyciu jednego owocnika Amanita muscaria o masie około 70 gramów (Satora et al. 2005, Stebelska 2013). Pierwsze objawy po spożyciu muchomora występują stosunkowo szybko, ponieważ już po około 15 do 30 minutach. Zwykle są to nudności, wymioty, biegunka, rozszerzenie naczyń krwionośnych, pocenie się i ślinotok. Interesującym efektem halucynogennym, który występuje po zjedzeniu muchomora jest zjawisko makroskopii. Polega ono na widzeniu otaczających przedmiotów jako znacznie większych, niż są one w rzeczywistości. W przypadku ludzi, doustne przyjęcie stosunkowo dużych dawek muscimolu prowadzi do hipertermii, rozszerzenia źrenic, poprawy nastroju, trudności z koncentracją, anoreksji, ataksji, katalepsji oraz halucynacji. Szereg tych zmian przypomina stan upojenia alkoholowego, jest także charakterystycznych do efektów powodowanych przez klasyczne związki halucynogenne, jak choćby LSD (Meyer \& Quenzer 2005). Objawy zatrucia muchomorem utrzymują się stosunkowo długo i ustępują po upływie około 8 godzin od spożycia grzybów (Satora et al. 2005).

\section{Podsumowanie}

Grzyby halucynogenne są spożywane od tysiącleci w celach rytualnych i religijnych. Substancje aktywne, psylocybina, psylocyna i muscimol są stosunkowo mało toksyczne i z reguły nie powodują uzależnień, charakterystycznych choćby kokainy lub opiatów. Niemniej jednak, ze względu na charakter wywoływanych halucynacji oraz indywidualne cechy organizmu, jak wiek, stan emocjonalny mogą być groźne dla zdrowia. $\mathrm{Z}$ kolei na ich powinowactwo do receptorów układu serotoninergicznego, a przez to na możliwość interakcji $z$ innymi systemami neurotransmisyjnymi mózgu, stanowią niebezpieczeństwo rozwoju psychoz, często charakterystycznych dla tych, występujących u pacjentów ze schizofrenią. Niezależnie od niebezpieczeństw związanych ze spożywaniem grzybów halucynogennych, jak też produkowanych przez nie substancji aktywnych, należy wskazać, że te ostatnie znajdują powszechne zastosowania $w$ badaniach neurofizjologicznych. Będąc agonistami lub antagonistami receptorów błonowych dla niektórych neurotransmiterów, pozwoliły zrozumieć ich funkcje fizjologiczna oraz wskazały na możliwe patologie powodowane zaburzeniami w obrębie poszczególnych systemów neurotransmisyjnych. 